\title{
PEMANFAATAN BAHAN LIMBAH CANGKANG SAWIT SEBAGAI BAHAN PENGISI AGREGAT KASAR PADA BETON
}

\author{
Hafiz Riadi ${ }^{1}$, Danil ${ }^{2}$ \\ ${ }^{1}$ Dosen Teknik Sipil, Universitas Islam Negeri Sunan Ampel, Jl. Ahmad Yani No. 117, Surabaya \\ Email: hafiscivil@gmail.com \\ ${ }^{2}$ Mahasiswa Jurusan Teknik Sipil, Universitas Samudra, Kampus Meurandeh Langsa, Telp 0641-7445019
}

\begin{abstract}
ABSTRAK
Indonesia merupakan salah satu negara agraris yang terbesar di dunia yang memiliki kekayaan alam dari sektor perkebunan diantaranya adalah perkebunan kelapa sawit. Hampir seluruh daerah di Indonesia memiliki lahan kelapa sawit yang luas dan tidak menutup kemungkinan limbah kelapa sawit akan melimpah pula. Salah satu pemanfaatan limbah yang dihasilkan oleh kelapa sawit yaitu dengan menggunakan Bongkahan Cangkang Sawit (BCS) sebagai bahan pengisi agregat kasar. Bongkahan Cangkang Sawit yang digunakan berasal dari Pabrik Pengolahan Kelapa Sawit (CPO) yang berasal dari Aceh Timur. paving block dan rabat beton lantai.
\end{abstract}

Kata kunci: Bongkahan Cangkang Sawi (BCS), agregat kasar

\section{PENDAHULUAN}

Kelapa sawit pertama sekali diperkenalkan di Indonesia oleh pemerintah Kolonial Belanda pada tahun 1848. Ketika itu ada empat bibit kelapa sawit yang dibawa oleh Mauritius dari Amsterdam dan ditanam di Kebun Raya Bogor dan mulai diusahakan dan dibudidayakan secara komersial di Indonesia oleh seorang berkebangsaan Belgia yang bernama Addrian Hallet yang mengusahakan perkebunan kelapa sawit di sungai liput aceh tamiang dan di pulau raja (Asahan) pada tahun 1911.

Mengingat perkembangan kelapa sawit di Indonesia yang terus meningkat, selain produksi minyak kelapa sawit yang tinggi, maka produk samping atau limbah pabrik kelapa sawit juga semakin meningkat diantaranya limbah yang dihasilkan dalam pengolahan buah sawit berupa : tandan buah kosong, serat buah perasan, lumpur sawit (Solid Decanter), cangkang sawit, dan bungkil sawit. Saat ini pemanfaatan cangkang sawit di berbagai industri pengolahan minyak Crude Palm Oil (CPO) belum begitu maksimal.

Limbah kelapa sawit adalah limbah lignoselulosik yang merupaka limbah organic dan terdapat dalam jumlah yang sangat besar di alam. Sampai saat ini limbah tersebut belum dimanfaatkan secara optimal dan nilai ekonomin ya sangat rendah. Salah satu limbah lignoselulosik yang dimaksud adalah Cangkang Sawit sebagai limbah pengolahan kelapa sawit. Mengenai pemanfaatan limbah yang dihasilkan oleh tanaman kelapa sawit, maka salah satu usaha yang pernah dilakukan oleh Abdullah, dkk (2010) ialah dengan mengisi bahan campuran agregat, yaitu dengan Bongkahan Cangkang Sawit (BCS) pada proporsi tertentu dapat menghasilkan mutu beton > 25Mpa pada beton ringan busa. Ini menjadi potensi yang sangat baik dalam upaya menggantikan bahan agregat alami. Namun demikian pemanfaatan beton bertulang menggunakan agregat (BCS) belum menjadi perhatian sepenuhnya.

Dalam paper ini memaparkan tentang pemanfaatan limbah cangkang sawit sebagai bahan pengisi agregat kasar pada campuran beton.

\section{PROGRAM EKSPERIMENTAL}

Pada penelitian ini dipersiapkan benda uji kubus dengan ukuran (15 x 15 x 15) cm sebanyak 40 benda uji untuk pengujian kuat tekan. Pada penelitian ini menggunakan campuran beton dengan faktor air semen (FAS) adalah 0,5. Detail jumlah benda uji dari rencana penelitian dapat dilihat pada Tabel di bawah ini. 
Tabel 1. Jumlah benda uji kubus dengan penambahan agregat Bongkahan Cangkang Sawit (BCS)

\begin{tabular}{cccccc}
\hline \multirow{2}{*}{ Benda uji } & \multicolumn{4}{c}{ Umur Beton } & \multirow{2}{*}{ Jumlah } \\
\cline { 2 - 5 } & $\mathbf{7}$ hari & $\mathbf{1 4}$ hari & $\mathbf{2 1}$ hari & $\mathbf{2 8}$ hari & \\
\hline Kubus $15 \times 15 \times 15$ & 5 & 5 & 5 & 5 & 20 \\
\hline \multicolumn{5}{c}{ Jumlah total } \\
\hline
\end{tabular}

(Sumber: Arjuna, 2010)

Tabel 2. Jumlah benda uji kubus tanpa penambahan agregat Bongkahan Cangkang Sawit (BCS)

\begin{tabular}{|c|c|c|c|c|c|}
\hline \multirow{2}{*}{ Benda uji } & \multicolumn{4}{|c|}{ Umur Beton } & \multirow{2}{*}{ Jumlah } \\
\hline & 7 hari & 14 hari & 21 hari & 28 hari & \\
\hline Kubus $15 \times 15 \times 15$ & 5 & 5 & 5 & 5 & 20 \\
\hline \multicolumn{5}{|c|}{ Jumlah total } & 20 \\
\hline
\end{tabular}

(Sumber: Arjuna, 2010)

\section{CANGKANG KELAPA SAWIT}

Tempurung kelapa sawit merupakan salah satu limbah pengolahan minyak kelapa sawit yang cukup besar, yaitu mencapai $60 \%$ dari produksi minyak. Tempurung buah kelapa sawit dapat dimanfaatkan sebagai arang aktif, yang dimanfaatkan oleh berbagai industri, antara lain industri minyak, karet, gula dan farmasi. Selain itu tempurung kelapa sawit digunakan hanya sebagai bahan bakar pembangkit tenaga uap dan bahan pengeras jalan.

Prinsip pemisahan biji dari cangkangnya adalah karena adanya perbedaan berat jenis antara inti dan cangkang. Caranya adalah dengan mengapungkan biji-biji yang telah dipecahkan dalam larutan lempung yang mempunyai berat jenis 1,16. Dalam keadaan ini inti kelapa sawit akan mengapung dalam larutan dan cangkang akan mengendap di dasar. Inti dan cangkang diambil secara terpisah kemudian dicuci sampai bersih. Alat yang digunakan untuk memisahkan inti dari cangkangnya disebut hydrocyclone separator. Inti buah dimasukkan ke silo dan dikeringkan pada suhu $80^{\circ} \mathrm{C}$, selama pengeringan harus dibolak-balik agar merata.

Hasil pembakaran dari cangkang dan serabut (fiber) dalam ketel uap (boiler) akan menghasilkan abu dan kerak atau bongkahan cangkang sawit (BCS), Abu hasil pembakaran ini biasanya dibuang dekat pabrik sebagai limbah padat dan dimanfaatkan oleh masyarakat sekitar sebagai bahan timbunan jalan ataupun sebagai bahan timbunan halaman.

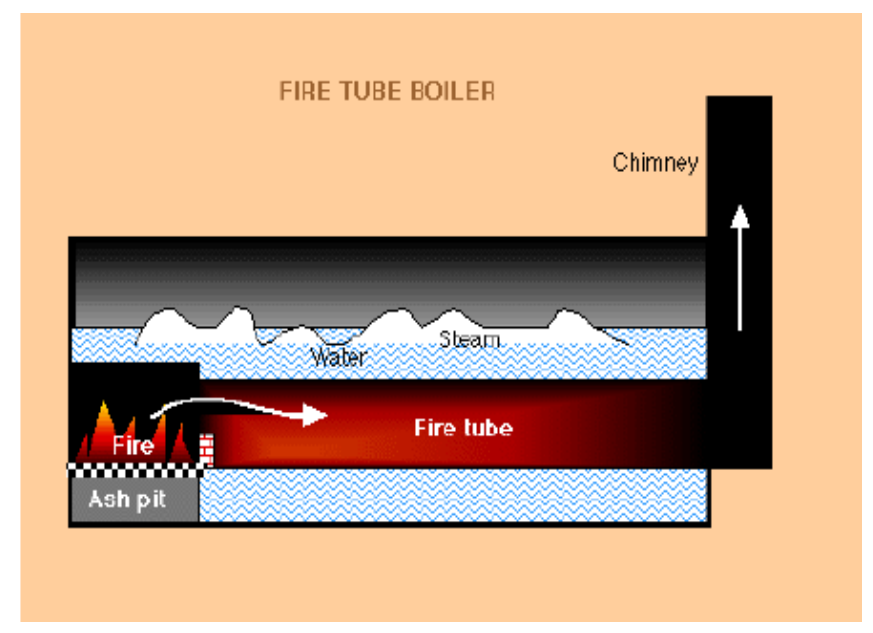

Gambar 1. Skema ketel uap (Boiler) 


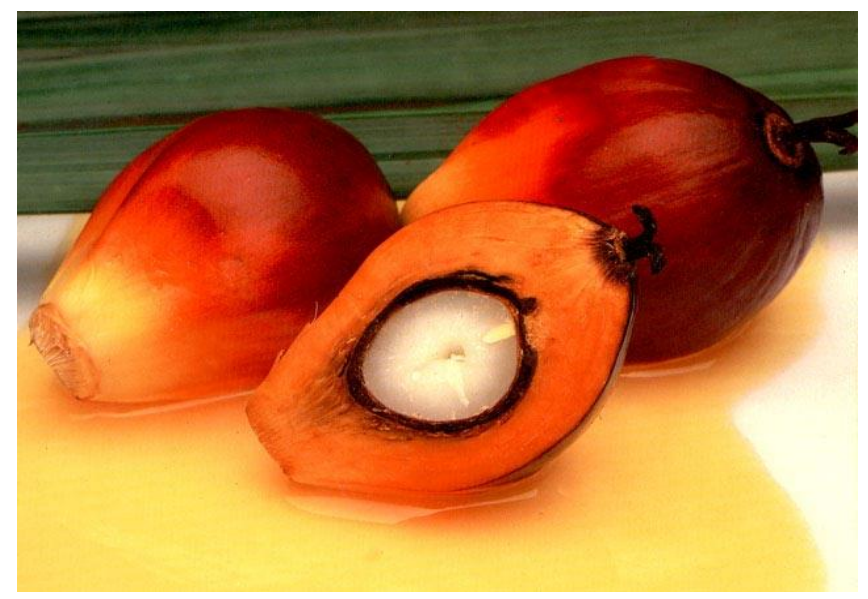

Gambar 2. Cangkang sawit

\section{ABU CANGKANG KELAPA SAWIT}

Dalam pemrosesan buah kelapa sawit menjadi ekstrak minyak sawit, menghasilkan limbah padat yang sangat banyak dalam bentuk serat, cangkang dan tandan buah kosong, dimana untuk setiap seratus ton tandan buah segar yang diproses akan didapat lebih kurang 20 ton cangkang, 7 ton serat dan 25 ton tandan kosong. Untuk membantu pembuangan limbah dan pemulihan energi, cangkang dan serat ini digunakan lagi sebagai bahan bakar untuk menghasilkan uap pada penggilingan minyak sawit. Setelah pembakaran dalam ketel uap, akan dihasilkan 5\% abu (Oil Palm Eshes) dengan ukuran butiran yang halus. Abu hasil pembakaran ini biasanya dibuang dekat pabrik sebagai limbah padat dan tidak dimanfaatkan. hasil uji komposisi unsur kimia dari abu cangkang kelapa sawit yang telah dilakukan oleh (Hutahaean, 2007) dapat dilihat pada tabel berikut :

Tabel 3. Unsur kimia abu cangkang kelapa sawit

\begin{tabular}{clc}
\hline No. & \multicolumn{1}{c}{ Unsur kimia } & Persentase $(\%)$ \\
\hline 1. & Silika Dioksida $\left(\mathrm{SiO}^{2}\right)$ & 58,02 \\
\hline 2. & Aluminium Oksida $\left(\mathrm{Al}^{2} \mathrm{O}^{3}\right)$ & 8,7 \\
\hline 3. & Besi Oksida $\left(\mathrm{Fe}^{2} \mathrm{O}^{3}\right)$ & 2,6 \\
\hline 4. & Kalsium Oksida $(\mathrm{CaO})$ & 12,65 \\
\hline 5. & Magnesium Oksida $(\mathrm{MgO})$ & 4,23 \\
\hline 6. & Hilang Pijar $(\mathrm{LOI})$ & 0,41 \\
\hline 7. & Silika Dioksida $\left(\mathrm{SiO}^{2}\right)$ & 0,72 \\
\hline 8. & Aluminium $\left.\mathrm{Oksida}^{2} \mathrm{Al}^{2} \mathrm{O}^{3}\right)$ & 1,97 \\
\hline 9. & Besi Oksida $\left(\mathrm{Fe}^{2} \mathrm{O}^{3}\right)$ & 8,59 \\
\hline Sumber: Hutahaean, 2007$)$ &
\end{tabular}

Dalam abu cangkang sawit mengandung $\left(\mathrm{SiO}_{2}\right)$, jika unsur silica $\left(\mathrm{SiO}_{2}\right)$ ditambahkan dengan campuran beton, maka unsur silica tersebut akan bereaksi dengan kapur bebas $\mathrm{Ca}(\mathrm{OH})_{2}$ yang merupakan unsur lemah dalam beton menjadi gel CSH baru. Gel CSH merupakan unsure utama yang mempengaruhi kekuatan pasta semen dan kekuatan beton.

Kerak/slag bolier yang disebabkan adanyan endapan-endapan deposit mineral yang mengeras. Fenomena ini sangat merugikan bagi pembakaran pada boiler, karena akan mengurangi efisiensi pertukaran panas. Penyebab fenomena ini adalah tekanan gas yang berbeda pada setiap bahan bakar yang mengakibatkan percikan pijar api dan partikel yang relatif ringan, namun tidak mampu keluar daripada mesin pengendap siklon dan akan melekat pada dindingdinding boiler. Sedangkan partikel yang ringan akan dikeluarkan melalui cerobong asap dan partikel yang relatif berat dan habis terbakar akan tertampung pada tempat abu yang berada dibawah tungku.

Slag/kerak boiler kelapa sawit ini adalah memiliki massa yang lebih berat daripada fly ash (abu terbang) yang keluar daripada cerobong asap, dan kerak boiler ini relatif memiliki pori-pori yang banyak. Pada umumnya kerak ini digunakan oleh Pabrik Kelapa Sawit sebagai pengeras jalan di sekitar pabrik. 


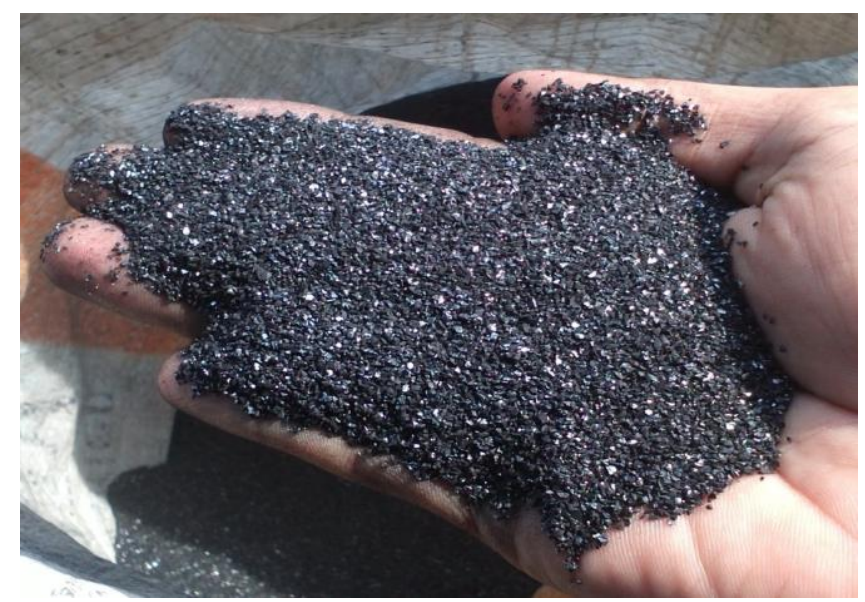

Gambar 3. Abu Cangkang Sawit

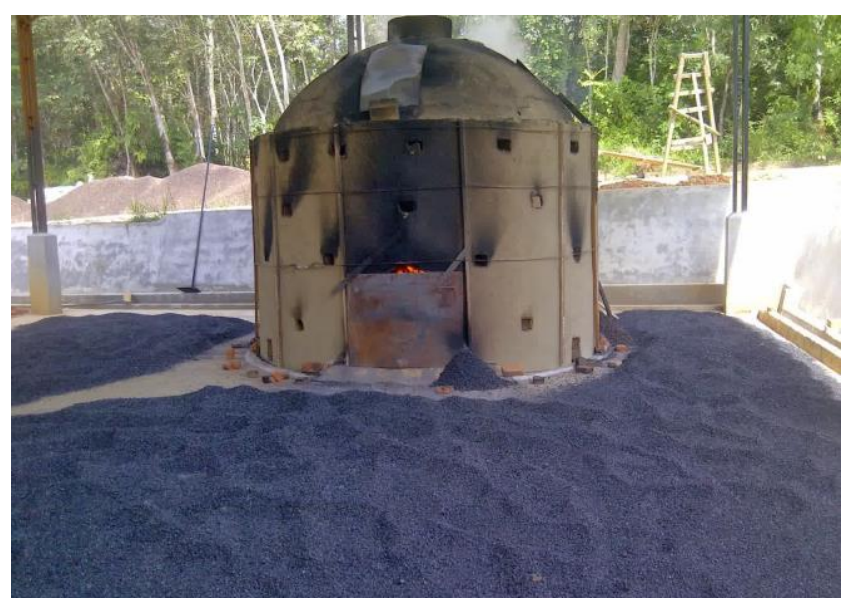

Gambar 4. Abu Cangkang Sawit dan Ketel (Boiler)

\section{HASIL DAN PEMBAHASAN}

\section{Pemeriksaan Fisis Bongkahan Cangkang Sawit (BCS)}

Pemeriksaan sifat fisis meliputi pemeriksaan berat jenis, daya serap air, modulus kehalusan. Hasil pemeriksaan digunakan untuk menentukan apakah agregat Bongkahan Cangkang Sawit (BCS) telah memenuhi syarat agregat ringan. Hasil pemeriksaan sifat fisis agregat Bongkahan Cangkang Sawit (BCS) dapat dilihat pada berikut ini :

Tabel 4. Pemeriksaan sifat fisis Bongkahan Cangkang Sawit (BCS)

\begin{tabular}{lc}
\hline \multicolumn{1}{c}{ Sifat-sifat fisis BCS } & Hasil rata-rata penelitian \\
\hline Berat jenis BCS keadaan kering permukaan (SSD) & 1,660 \\
\hline Berat jenis BCS keadaan kering (OD) & 1,637 \\
\hline Durabilitas BCS & $13,2 \%$ \\
\hline Daya serap air BCS & $1,409 \%$ \\
\hline Diameter BCS & lolos $=19,1 \mathrm{~mm}$, tertahan $=4,76 \mathrm{~mm}$ \\
\hline Sumber: Arjuna, 2010)
\end{tabular}


Tabel 5. Komposisi kandungan kimia BCS

\begin{tabular}{clc}
\hline No. & \multicolumn{1}{c}{ Unsur kimia } & Komposisi $(\%)$ \\
\hline 1. & Silika Dioksida $\left(\mathrm{SiO}^{2}\right)$ & 38,128 \\
\hline 2. & Aluminium $\left.\mathrm{Oksida}^{2} \mathrm{Al}^{2} \mathrm{O}^{3}\right)$ & 10,302 \\
\hline 3. & Besi Oksida $\left(\mathrm{Fe}^{2} \mathrm{O}^{3}\right)$ & 0,898 \\
\hline 4. & Kalsium Oksida $(\mathrm{CaO})$ & 3,926 \\
\hline 5. & Magnesium Oksida $(\mathrm{MgO})$ & 3,649 \\
\hline 6. & Hilang Pijar $(\mathrm{LOI})$ & 0,685 \\
\hline (Sumber: Arjuna, 2010$)$ &
\end{tabular}

\section{Hasil Pengujian Kuat Tekan}

Secara umum penambahan agregat Bongkahan Cangkang Sawit (BCS) memberikan kontribusi positif terhadap pencapaian kuat tekan beton, $\mathrm{f}^{\prime}$. Untuk lebih jelasnya dapat dilihat pada tabel dibawah ini :

Tabel 6. Perbandingan kuat tekan rata-rata beton dengan penambahan BCS dan tanpa penambahan BCS

\begin{tabular}{|c|c|c|c|}
\hline Umur & $\begin{array}{c}\text { Kuat tekan }\left(f^{\prime} c\right) \text { rata-rata dengan } \\
\text { penambahan BCS }(15 \%)\end{array}$ & $\begin{array}{l}\text { Kuat tekan }\left(f^{\prime} c\right) \text { rata-rata } \\
\text { tanpa penambahan BCS }\end{array}$ & Selisih \\
\hline (hari) & $\left(\mathrm{kg} / \mathrm{cm}^{2}\right)$ & $\left(\mathrm{kg} / \mathrm{cm}^{2}\right)$ & $(\%)$ \\
\hline 7 & 106,133 & 116,444 & 9 \\
\hline 14 & 152,000 & 148,000 & -3 \\
\hline 21 & 155,022 & 169,333 & 8 \\
\hline 28 & 163,111 & 176,000 & 7 \\
\hline
\end{tabular}

Tabel 7. Penggolongan Beton dengan Penambahan BCS

\begin{tabular}{cccc}
\hline $\begin{array}{c}\text { Umur } \\
(\mathbf{h a r i})\end{array}$ & Persentase BCS & $\begin{array}{c}\text { Kuat tekan }\left(\boldsymbol{f}^{\prime} \boldsymbol{c}\right) \\
\text { rata-rata }\end{array}$ & Penggolongan kelas beton \\
\cline { 2 - 3 } & $\mathbf{( \% )}$ & $\left.\mathbf{k g} / \mathbf{c m}^{\mathbf{2}}\right)$ & \\
\hline 7 & 15 & 106,133 & Moderate Strength Concretes \\
\hline 14 & 15 & 152,000 & Moderate Strength Concretes \\
\hline 21 & 15 & 155,022 & Moderate Strength Concretes \\
\hline 28 & 15 & 163,111 & Moderate Strength Concretes \\
\hline
\end{tabular}

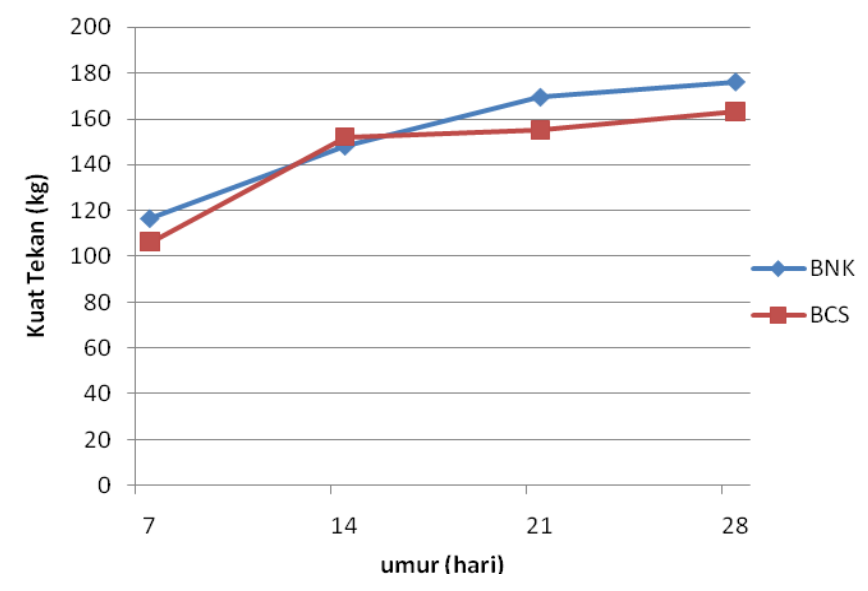

Gambar 5. Kuat tekan beton dengan penambahan dan tanpa penambahan agregat BCS

Dari hasil pengujian kuat tekan beton dengan penambahan agregat Bongkahan Cangkang Sawit (BCS), maka penggolongan kelas beton berdasarkan kuat tekan yang tercapai dapat digolongkan menjadi Moderate Strength Concretes. Dari hasil pengujian kuat tekan beton juga dapat dilihat bahwa penambahan agregat Bongkahan Cangkang Sawit (BCS) sebesar $15 \%$ dapat menghasilkan nilai kuat tekan rata-rata beton sebesar $163,111 \mathrm{~kg} / \mathrm{cm}^{2}$. 
Dari hasil pengujian kuat tekan beton juga dapat dilihat bahwa tanpa penambahan agregat Bongkahan Cangkang Sawit (BCS) nilai kuat tekan rata-rata beton sebesar $176,00 \mathrm{~kg} / \mathrm{cm}^{2}$.

Dari hasil pengujian kuat tekan juga dapat dilihat bahwa penambahan agregat Bongkahan Cangkang Sawit (BCS) sebesar $15 \%$ hasil kuat tekan yang dicapai lebih rendah apabila dibandingkan dengan tanpa penambahan agregat Bongkahan Cangkang Sawit (BCS). Hal ini diakibatkan karena proporsi persentase penambahan agregat Bongkahan Cangkang Sawit (BCS) pada proporsi tersebut belum optimal. Sehingga diperlukan adanya kajian-kajian dan penelitian-penelitian lebih lanjut.

\section{KESIMPULAN}

Kesimpulan yang dapat disajikan dalam pembahasan paper ini adalah sebagai berikut :

1. Dari hasil pengujian kuat tekan beton, penambahan agregat Bongkahan Cangkang Sawit (BCS) sebesar $15 \%$ menghasilkan nilai kuat tekan rata-rata beton sebesar $163,111 \mathrm{~kg} / \mathrm{cm}^{2}$.

2. Dari hasil pengujian kuat tekan beton dapat dilihat bahwa tanpa penambahan agregat Bongkahan Cangkang Sawit (BCS) nilai kuat tekan rata-rata beton sebesar $176,00 \mathrm{~kg} / \mathrm{cm}^{2}$.

3. Proporsi penambahan agregat Bongkahan Cangkang Sawit (BCS) sebesar $15 \%$, bukan merupakan persentase optimum dalam peningkatan nilai kuat tekan beton.

\section{DAFTAR PUSTAKA}

Abdullah, Afifuddin Moch dan Huzaim. (2010). "Pemanfatan Bahan Limbah Sebagai Pengganti Semen pada Beton Busa Mutu Tinggi”. Konferensi Nasional Teknik Sipil 4, halaman S - 365 - 370.

ASTM. (1989). standard specification for fly ash and raw or calcined natural pozzolanafor use as a mineral admixture in Portland cemen concrete. ASTM C 618-89, Philadepphia.

Arjuna, M. (2010). Perilaku Geser Balok Beton Busa Bertulang Menggunakan Bongkahan Cangkang Sawit. Tesis, Universitas Syiah Kuala Darussalam, Banda Aceh.

Huthaean, B. (2007). Pengujian Sifat Mekanik Beton Yang Dicampur Dengan Abu Cangkang Sawit. Skripsi, Jurusan Fisika, FMIPA UNIMED, Medan.

Mc Cormac Jack. (2003). Desain Beton Bertulang. Edisi ke 5 Jilid 1. Jakarta : Erlangga.

Macgregor, J.G (1997). Reinforced Concrete Mechanics and Design. Third Edition. USA : Prentice-Hall International, Inc.

Nawy, Edward G (2008). Beton Bertulang. Bandung : Refika Aditama.

Neville, A.M., and Brooks, J.J (2003). Concrete Technology. London : Longman.

Park, R and Paulay, T (1975). Reinforced Concrete Structure. New York : John Wiley\& Sons. Inc.

Subiyanto Bambang, Triastuti dan Rosalita Yetvi (2007). Komponen Kimia Cangkang Sawit (Elaesis Guineensis Jacq) dan Pengaruhnya Terhadap Sifat Beton Ringan. UPT Balai Litbang Biomaterial - LIPI.

Siregar Pordinan (2008). "Pemanfaatan Abu Kerak Boiler Cangkang Kelapa Sawit Sebagai Campuran Semen Pada Beton". Tugas Akhir. Universitas Sumatera Utara, Medan. 